\title{
What might take the place of late-generation European American ethnicity?
}

\section{Citation}

Sollors, Werner. 2014. "What Might Take the Place of Late-Generation European

American Ethnicity?" Ethnic and Racial Studies 37 (5) (March 18): 778-780.

doi:10.1080/01419870.2013.876060.

\section{Published Version}

doi:10.1080/01419870.2013.876060

\section{Permanent link}

http://nrs.harvard.edu/urn-3:HUL.InstRepos:31902679

\section{Terms of Use}

This article was downloaded from Harvard University's DASH repository, and is made available under the terms and conditions applicable to Open Access Policy Articles, as set forth at http:// nrs.harvard.edu/urn-3:HUL.InstRepos:dash.current.terms-of-use\#OAP

\section{Share Your Story}

The Harvard community has made this article openly available.

Please share how this access benefits you. Submit a story.

Accessibility 
It is hard not to agree with Herbert Gans. This was the case when he wrote "Symbolic Ethnicity," as it is the case now that he is confronting the situation of LGE's in America today. His central hypothesis of the gradual attenuation of ethnic structures and cultures, private ethnic practices, and the strength of the sense of ethnic identity among fourth-, fifth-, and later-generation European immigrant descendants, to such an extent that one can speak not just of a twilight but of a disappearance of their ethnicity, seems quite plausible and could probably be tested and verified with the empirical research projects he suggests.

Let me merely make five additional suggestions for the consideration of contexts that might affect the future of LGE's in the United States. Two suggestions, concerning nostalgia and intermarriage, expand on keywords discussed by Herbert Gans, while three others, about multiculturalism, travel-andcommunication, and dual citizenship, represent further contexts for possible consideration in future research projects.

1. Nostalgia: If symbolic ethnicity is by now largely nostalgic for LGE's, it might be worth keeping in mind that nostalgia can be contagious and directed toward pasts that never existed (Boym 2001). Thus "feeling Italian" may be such a widely shared sense of identity in the United States that it extends to people who do not claim any Italian ancestry, not even a very remote one (Ferraro 2005). As Herbert Gans writes, LGE's may no longer know the names of their immigrant ancestors, but as any visitor to the National Archives can confirm, Americans love genealogical researches and "ancestry-hunting," though they may often be content to find either generic percentages of European, African, Asian, and Native American elements in their ethnic makeup, as in the breakdowns produced by popular DNA data banks, or they may accept genetic links to particularly famous ancestors-like Charlemagne - that hosts of TV shows may surprise them with. 
2. Intermarriage: It might be interesting to find out how many intermarriages between Asian immigrants and whites, or between Latino immigrants and whites, are actually intermarriages with whites who are LGE's. This also raises the further question how many people who might be identified as "people of color" in America could also, and perhaps may indeed, identify as LGE's. It may not be a significantly large group, but it is a group that might still indicate a way of LGE's disappearing into an American identity, but not exclusively as whites.

3. Multiculturalism: The fact that current LGE's live in an environment in which multiculturalism has replaced assimilation and Anglo-conformity as a primary way toward national belonging may also affect their practices and identity choices.

Multiculturalism has reduced forms of sadism toward outgroups (Rorty 1998) which has also made ethnic mobilization against stereotyping and prejudice less necessary. Today Italian Americans can more easily enjoy American popular culture about the mafialike The Sopranos - than earlier generations were able to. Multiculturalism has also stimulated a more generalized pride in diversity, making it less urgent to settle on only one particular ethnic origin.

4. Travel-and-communication: Perhaps it has never been easier than in the past two decades or so for Americans, including LGE's, to travel to West and East European countries, to virtually all European countries of origin of the second wave of "new immigration" from the 1880 s to the 1920s. May repeated visits by LGE's to their (real or assumed) ancestral homelands affect their sense of identity and increase their wish to learn heritage languages or reintroduce current (rather than past) cultural and culinary practices from such countries to their American homes? Does the new technological ability to keep in touch with old relatives and new friends in such countries via media like Skype further encourage such activities among LGE's? 
5. Dual citizenship: A significant difference from the situation of earlier immigrant generations lies in the new readiness of the United States and a number of other countries to accept dual citizenship (Schuck 2002). A Greek or an Italian surname or a remote Irish connection can quickly lead an LGE to a European Union passport and to increased opportunities of employment or of purchasing property. Will this situation affect their sense of belonging? Will dual citizenship also play a role in the future development of ethnicity among Asian and Latin American migrants and their descendants today? Is it possible then that while the old ethnic ways keep disappearing new transnational practices and sentiments may take their place? In other words, might we have to expect new transnational practices (Polish hip-hop) rather than ethnic revivals (Polish polka) among LGE's in the US?

--Werner Sollors

\section{References}

BOYM, S. 2001 The Future of Nostalgia. New York: Basic Books

FERRARO, T. 2005 Feeling Italian: The Art of Ethnicity in America. New York: New York University Press

RORTY, R. 1998 Achieving Our Country: Leftist Thought in Twentieth-Century America. Cambridge MA and London: Harvard University Press

SCHUCK, P. 2002 'Plural Citizenships.' In R. Hansen and P. Weil, eds. Dual Nationality, Social Rights and Federal Citizenship in the U.S. and Europe: The Reinvention of Citizenship. New York: Berghahn Books. 61-99 